\title{
TRUTH AS RATIONAL ACCEPTANCE OF KNOWLEDGE
}

\author{
Aravan B. Tazayan \\ Don state technical university. Rostov-on-Don, Russian Federation \\ tazayanab@yandex.ru
}

It is considered epistemological difficulties of the truth correspondent concept, solution of which determines the qualitative transformation of the scientific cognition goal.It has been carried out the analysis of the correspondence concept, which indicates that it does not have the necessary theoretical resources of justification as a criterion of truth. This circumstance refutes the view of the uniqueness and universality of the truth correspondent concept. It is not refuted, but its epistemological status is significantly altered. Truth corresponding conception appears to be as one of the possible epistemological hypotheses along with others. A new look at the correspondent theory of truth opens new prospects for scientific rationality, corrects its cognitive resource. The rational acceptability concept of knowledge comes to replace the truth knowledge as a correspondence of knowledge to the reality. It is emphasized that the given "truth" concept evolution is not a result of alternative points of view criticism, but is a consequence of self-correcting scientific practice, and its new philosophical concept is based on the achievements of non-classical science. This thesis is confirmed by the scientific standards that scientific community is guided by. For the first time this question was investigated by K. Popper in the philosophy of science. In the result of his research, he formulated two methodological positions that are explicitly or implicitly presented in science: the concepts of phallibilism and falsificationism. The article points out that Popper's pioneering ideas have developed in modern American analytical philosophy. This conclusion is supported by the views review of $\mathrm{H}$. Patnem. Summing up, it is given a positive assessment of these changes in the theory of knowledge. The truth concept as rational acceptability overcomes a number of epistemological difficulties, which appear to be in disparity of goals and results of scientific activity.

Key words: knowledge, corrective concept of truth, rational acceptability, object, subject, experience, empiricism.

\section{[Тазаян А. Б. Истина как рациональная приемлемость знания]}

Рассматриваются гносеологические трудности корреспондентной концепции истины, решение которых обусловливает качественную трансформацию цели научного познания. Представлен анализ концепта соответствия, который указывает, что у него в качестве критерия истины нет необходимых теоретических ресурсов обоснования. Данное обстоятельство опровергает точку зрения о единственности и универсальности корреспондентной концепции истины. Она не опровергается, но существенно изменяется ее гносеологический статус. Корреспондентная концепция истины предстает как одна из возможных гносеологических гипотез наряду с другими. Новый взгляд на корреспондентную теорию истины открывает новые перспективы для научной рациональности, корректирует ее познавательный ресурс. На смену познания истины, как соответствия знания действительности, приходит концепция рациональной приемлемости знания. Подчеркивается, что данная эволюция концепта «истина» не есть результат критики альтернативных точек зрения, а является следствием самокорректирующей научной практики, а ее новая фрилософская концепция опирается на достижения неклассической науки. Подтверждается данный тезис стандартами научности, которыми руководствуется научное сообщество. В фрилософиии науки впервые данный вопрос исследовал К. Поппер. В результате своих исследований он сфрормулировал два методологических положения, которые в явной или в неявной форме представлены в науке: концепции фаллибилизма и фальсификационизма. Указывается, что пионерские идеи Поппера получили развитие в современной американской аналитической философии. Данный вывод подкрепляется обзором взглядов Х. Патнэма. В заключении дается положительная оценка этим изменениям в теории познания. Концепция истины в качестве рациональной приемлемости, преодолевает ряд гносеологических трудностей, которые предстают в несоразмерности целей и результатов научной деятельности.

Ключевые слова: знание, корреспондентная концепция истины, рациональная приемлемость, объект, субъект, опыт, эмпиризм. 
Aravan B. Tazayan - Ph.D. of philosophy. Don state technical university. Rostov-on-Don, Russian Federation.

Тазаян Араван Бабкенович - доктор философских наук. Донской государственный технический университет. г. Ростов-на-Дону, Россия.

The goal of knowledge is truth. Historically, the first form of truth is the correspondent concept. According to it, knowledge is genuine, if it corresponds to the reality. In an explicit form, the correspondent conception of truth is presented in Aristotle's Metaphysics. "... To talk about existing, that it is not, or about non-existing, that it is, - he writes, -means to speak genuine truth" [1]. In this definition, Aristotle defines the conditions for the truth of knowledge - its correspondence to the object. The given definition is based on two assumptions: a) the existence of reality external to the subject; b) correspondence of knowledge to the reality. These two conditions are presented in various interpretations of the "reality" and "conformity" concepts. But all supporters of the correspondent theory are united by the adoption of a single truth structure: 1) a judgment that represents truth must have something external to itself; 2) the judgment must correspond to its referent; 3 ) such correspondence is true.

Aristotle also emphasizes that there is no intermediate state between truth and falsehood. That is, the knowledge truth value is strictly binary - it is either true or false (the disjunction here is represented in a strictly separatory aspect). In the correspondent conception of truth, the question about procedure for correspondence establishing of knowledge to the world did not receive a satisfactory solution. How can you say that the world is exactly what our knowledge of it is, if all that we know about the world comes down to the knowledge we have? In the last resort, what is the procedure for establishing this correspondence. It seems that the procedure for establishing a correspondence has two solutions: either with the inevitability of a "logical circle" fact accepting, or assuming the existence of a premise that has nothing to do with knowledge in general (for instance, practice, as by Marx).

An equally important correspondent concept of truth is the question of achieving logical consistency of judgments in the cognition process. If our knowledge is the external world reflection result, then how is the consistency between the world of things and knowledge achieved? In fact, we formulate and accept the rules for the formation and transformation of judgments prior knowledge of the external world. Of course, we are doubtful about the veracity of the Parmenidemetaphysical foundationsabout the thinking and being identity.But this supposition is necessary for the establishment of a cognitive relationship between the subject and the object, the transition condition from a sensory images sequence to a logical structure. The question about the subject and the object interaction presupposes a conceptual solution of two questions: what and how do we learn? Conceptual preferences, determining their gnoseological status, form various gnoseological doctrines.

A subject has two abilities through which it establishes a connection with an object. "Our knowledge arises from two main sources of the soul, - writes I. Kant, - the first of these is the ability to receive representations (receptivity to impressions), and the second is the ability to cognize an object through these representations (spontaneity of concepts). The object is given to usthrough the first ability, by the second it is conceived in relation to the representation (as the only soul determination)"[3].Not all philosophers separate Kant's point of view. Empiricists who claim that all cognition arises from experience are the most influential opponents of Kant's apriorism. It seems to empiricists that experience over- 
comes the apriorism weakness bases. But the overcoming of apriorism by empiricism is an imaginary. What is experience? If experience is the result of sensory impressions, which form our ideas about the external world, then the question about the world nature remains open, in what relation is the sensual image of reality with reality? This aspect raises the question of the experience objectivity. The connection of the subject with the external world is realized exclusively through sensory impressions in empiricism.How can subjective impressions transform into objective statements? Studies on neurophysiology allow us to assert that many different sensory perceptions are synthesized by our consciousness into a holistic image. The image is not a mechanical sum of sensations. In what relation the image and the complex of these sensations are - does not have an unequivocal scientific solutiontoday. Therefore, we must admit that Kant's apriorism criticism by empiricism can claim as an alternative point of view. Kant, as is known, sensations, and their synthesis, considered in the context of the abilities of the subject, considering the image as a construction that expresses the attitude of the reality subject. The boundary between the images-constructs and the "thing-in-itself", according to Kant, is insuperable. To cut this "Gordian knot" is possible only in one case - if we abandon the epistemological monism, the fundamental principle of thinking and being identity.

Thus, considering the abovementioned uncertainty, the question: what learns the subject, if the cognition object is not connected with reality, is considered to be appropriate. The difficulties of the truth correspondent conception are represented not only in the question about informative correspondence of the reality cognition. But as we have already noted, the question of the knowledge logical correspondence to the reality is also very important. Nonclassical mathematics, quantum mechanics indicate that there is no universal unambiguous structural correspondence between knowledge and the object of knowledge. Euclidean geometry and physical geometry, classical physics and general relativity represent different structures of the same reality context. The hypothesis of a logical gap between our knowledge and the outside world has the right to exist. It has become the subject of close study, both in philosophy and in science.

In the modern philosophy of science, where many points of view are presented, there is solidarity in one - there are no convincing rational grounds to assert that our knowledge in its content is a mirror image of reality. There is no doubt about the influence of the physical on the mental. The nature and extent of this influence on the cognitive process is the subject not only of philosophical discussions, but also of science. Arguments, even if they rely on the achievements of natural science, do not strengthen the position of empiricism and do not refute Kant's apriorism. Kant realized the impossibility of solving the epistemological relationship between the subject and the object, if object is accepted as an entity independent of the subject. If the external world is accepted as the reason of experience, then epistemology has the resources of a rational argument for the possibility of knowledge.

Alternative conceptualization of classical epistemology presupposes structural deconstruction of subject-object relations. The proposed structure includes three elements: an object as an objective reality, a subject and direct data, as a representation of an object that does not have a meaningful connection with the last one. How then is the perceptions unity formed in different subjects?Certainly, we are not able to establish the context of intersubjectivity, relying on our own feelings. This situation is in a certain sense analogous to the Cartesian "Cogito" - argument and does not allow the subject from the conditions of awareness of the personal"I" to assert the reliability of another subject. In this situation there is no direct logical transition. The universality and necessity of consciousness authenticity, as is known, is achieved by Descartes through the hypothesis of innate universal mental structures. But this additional assumption does not give persuasion torational arguments forjustifying the knowledge objectivity. Therefore, the new conception of the 
justifying objectivity methods (in our case of intersubjectivity) is viewed in a different plane. Own images of one knowledge subject can become the "property" of another subject through its referent. The referent, which can connect the two subjects, is a symbol with a social dimension, that is, cognition appears as an act of communication. Images, formed in personal experience, through verbalization, acquire general validity, enriching the lexical volume of the language. The question about the subjective experience sense is excluded, in this context only the meaning of the image takes place. Thus, language as a conceptual scheme is an implicit means of denoting personal experience in terms of social significance. Therefore, the concept can be considered as a form of mental activity, as an invariant that synthesizes a chaotic flow of external data into a structure and represents a rational aspect of the language. The cognitive process itself demonstrates the absence of a logical connection between the image and its invariant. If the social invariantsattach importance to their "images", then statements - the conceptual conditions of their functioning (syntactic and semantic rules). K. Popper expressed bewilderment mainly in connection with this circumstance, who argued that those who try to prove the veracity of a judgment, referring to the testimony of feelings, are similar to those who prove their rightness by "pounding the table with their fists" $[5 ; 6]$. The new epistemological concept is largely conformed with the doctrine of neopositivism: the world as a given cannot be described in rational terms, it acts as an unavoidable formal condition that makes the cognitive process possible.Therefore, the results of the cognitive process in the strict sense arethe structures description and their numerical relationships.

The positive evaluation of neopositivist epistemology, which proved to be a significant step in overcoming the epistemological difficulties of classical philosophy, does not release it from criticism. The program of criteria for the rational acceptability of knowledge, created by neo-positivists, is quite realistic, but the methods for its implementing are inconclusive. First of all, the principle of verification demonstrated its theoretical failure. The prerequisite underlying the verification criterion seems to be problematic: any synthetic proposition is associated in one single sphere of possible sensory data; and from the conviction that any judgment, taken in isolation from others, can be corroborated or refuted. The first premise is not obvious. In this regard, L.Wittgenstein made a witty remark: "All my experience shows that this is so. But how is this done? After all, a proposal in favor of which experience testifies, is itself connected with some special interpretation of experience" [2]. According to Wittgenstein, one cannot exclude the possibility that the sum of certain sensory impressions can have different interpretations. It can be reduced to the context of logical interpretation, as in neopositivists, but this is not the only interpretation. Critics of the neo-positivist approach point out that there are many possibilities between sensory data and its linguistic description. There is not one single relevant link between judgment and the sensory data sphere. The assertion of the compulsory nature of perception and the uniform impact of reality on different feelings cannot be accepted.

The doctrine of empiricism in the face of neo-positivism, also as rationalism, did not provide convincing arguments in resolving the knowledge source problem. Their most important arguments turned out to be associated with the human perception psychology. All attempts to separate the logical from the psychological were not entirely successful. At best, these results can be taken as a palliative. Considering the absence of theoretical clarity in question about human perception, about the way ofconnection of senses and image, the problem of knowledge referent stays to be open. The problem uncertainty of the knowledge referent is directly connected with the philosophical doctrine of truth.The concept of knowledge rational acceptability is one of the attempts to solve the above mentioned difficulties. In the philosophy of science (in scientific epistemology), it is represented in the works of Popper, T. Kun, P. Feyerabend. This concept was widely supported by modern analytical American philosophy (H. Patnam, D. Davidson, and others). 
Truth as rational acceptability can be treated as a process of approximation to objectivity (Popper), or to be "colored" in subjective tones (Putnam). "The variety of the ideal coherence of our beliefs is with each other", asPutnam writes, "and the data of our experience, to the extent that these data are representative in our belief system, but not at all consistent with the "state of affairs" independent of consciousness or speech [4].In Patnem'sinterpretation, rational acceptability appears as a multitude of possibilities for rational description of one and the same aspect of reality. Truth theoretical platform is practically offered for them. Patnem's notes that today nobody confirms that correspondence between knowledge and the external world objects has mutually univocal character, but a subdued form is also not acceptable, i.e. we cannot confirm that the there is contextual connection between signs and external things. "To explain,- writes Patnem,- acting in the role of the main reason that I have convictions containing a certain sign, may not at all be referents of this sign"[4,73].

Thus, the concept of truth, as the rational acceptability of knowledge, rejects the conformity criterion. For Patnem, this question sounds rhetorically: truth, like the theory of correspondence, has outlived itself and must be discarded. "We are present at the demise of a theory that has existed for almost two thousand years. The fact that this theory existed for so long and took so diverse forms ... it is obliged to the naturalness and the desire power to occupy the Divine Eye Point of View" [4,102]. The rejection from the "Divine Vision" doctrine presupposes the adoption of a new paradigm that could preserve the dignity of man as an intelligent being and at the same time reveal a refusal of pride and unreasonable claims. In the context of the new paradigm, a premise that indicates the heterogeneity of knowledge, experiencing many of our conceptual preferences, must be introduced.

\section{Лumepamypa}

1. Аристотель. Метафизика //Соч. В 4 т. М., 1975. Т. 1.

2. Витгенштейн Л. О достоверности //Философские работы. В 2т. М., 1994. Т.1.

3. Кант И. Критика чистого разума //Собр. соч. В 6 т.

4. Патнэм Х. Разум, истина, история. М., 2002.

5. Поппер К. Логика научного исследования // Поппер К. Логика и рост научного знания. М., 1983.

6. Getmanov I., Tazayan A.Coevolutional-methodological approach to cultural dialogue research // НаучныйальманахстранПричерноморья. 2017. № 3 (11).http://science-almanac.ru/new-issue.php

\section{References}

1. Aristotle. Metaphysics // Works. In 4 vols. M., 1975. Vol. 1.

2. Wittgenstein L. On the reliability // Philosophical works. In 2 vol. M., 1994. Vol.1.

3. Kant I. Critique of pure mind // Collected Works.in 6 volumes.

4. Patnem H. Mind, truth, history. M., 2002.

5. Popper K. The logic of scientific research // Popper K. Logic and the growth of scientific knowledge. M., 1983.

6. Getmanov I., Tazayan A.Coevolutional-methodological approach to cultural dialogue research // Science almanac of Black Sea region countries. 2017. № 3 (11).http://science-almanac.ru/new-issue.php 